\title{
PENERAPAN PENDEKATAN SAINTIFIK UNTUK MENINGKATKAN HASIL BELAJAR IPS MATERI FAKTOR MUNCULNYA RASA KEBANGSAAN DI INDONESIA PADA SISWA KELAS V SD SEMESTER GENAP DI SDN RAWAMANGUN 01 PAGI
}

\author{
${ }^{1}$ Shinta Sari, ${ }^{2}$ Rina Permatasari, ${ }^{3}$ Linda Ika Mayasari \\ Pendidikan Guru Sekolah Dasar, STKIP Kusuma Negara Jakarta, Indonesia \\ e-mail : shintasari@stkipkusumanegara.ac.id, rinapermatasari.emir@gmail.com, \\ lindaika_86@yahoo.com
}

\begin{abstract}
Abstrak
Penelitian ini bertujuan untuk meningkatkan hasil belajar IPS siswa menggunakan penerapan pendekatan saintifik dalam materi faktor munculnya rasa kebangsaan di Indonesia pada siswa kelas V SDN Rawamangun 01 Pagi Jakarta Timur semester genap tahun pelajaran 2019/2020.Metode penelitian ini adalah Penelitian Tindakan Kelas (PTK) yang mengikuti model Kemmis dan Taggart. Teknik pengumpulan data menggunakan teknik observasi, tes, dokumentasi, wawancara, dan catatan lapangan. Hasil penelitian menunjukkan bahwa penerapan pendekatan saintifik dapat meningkatkan hasil belajar IPS yang signifikan. Hal ini dibuktikan dengan hasil rata-rata tes IPS pada setiap siklus meningkat yaitu pada siklus I siswa yang mencapai KKM (72) sebanyak 17 siswa $(60,71 \%)$, pada siklus II meningkat menjadi sebanyak 23 siswa $(82,14 \%)$. Untuk persentase nilai aktivitas guru pada siklus I sebesar $76,67 \%$ dan pada siklus II sebesar $86,67 \%$, serta hasil wawancara yang dilakukan menyimpulkan bahwa belajar IPS melalui penerapan pendekatan saintifikdapat meningkatkan hasil belajar IPS siswa kelas V SDN Rawamangun 01 Pagi Kecamatan Pulogadung Jakarta Timur.
\end{abstract}

Kata kunci : Pendekatan Saintifik, Penelitian Tindakan Kelas, Hasil Belajar IPS

\begin{abstract}
The aim of the study is to improve students' social science subject learning results using scientific approach on topic: the factor appeared of the sense of nationality in Indonesia for 5th grade students of SDN Rawamangun 01 Pagi Jakarta Timur on the second semester of 2019/2020. The method of the study is Classroom Action Research by following Kemmis and Taggart Model. The data collection techniques are by using observation, test, documentation, interview, and field notes. The result of the study shows the applying of scientific approach can improve students' social science subject learning results significantly. It is proved from the improvement of the mean of social science subject test on every cycle: cycle I - students that passed the test standard (72) are 17 students (60,71\%), on the cycle II - it is improved to 23 students (82,14\%). The teachers' activity value percentage on the cycle I is $76,67 \%$ and $86,67 \%$ on the cycle II, and the interview result shows that the applying of scientific approach can improve students' social science subject learning results of the 5th grade students of SDN Rawamangun 01 Pagi Pulogadung, Jakarta Timur.
\end{abstract}

Keyword : Scientific Approach, Classroom Action Research, Social Studies Learning Outcomes 


\section{PENDAHULUAN}

Indikasi menurunnya moralitas generasi muda menuntut pembelajaran IPS berkontribusi untuk menumbuhkan moralitas dan karakter sosial peserta didik menjadi generasi penerus bangsa yang baik. Untuk itu, seorang pendidik harus mampu memahami bagaimana siswa memperoleh pengetahuan dari kegiatan belajar. Mengenai hal ini guru berarti sebagai ujung tombak pelaksanaan pendidikan di lapangan diharapkan dapat berperan sebagai fasilitator yang akan memfasilitasi siswa dalam belajar sehingga tujuan pembelajaran dapat tercapai dengan baik.

Berdasarkan hasil observasi dan wawancara peneliti dengan guru kelas V SD Negeri Rawamangun 01 Pagi Jakarta Timur dapat disimpulkan bahwa hasil belajar IPS siswa umumnya tidak signifikan karena sebelumnya menggunakan metode berkelompok sehingga ada siswa/i yang saling mengandalkan, nilai dari ulangan harian IPS materi munculnya rasa kebangsaan di Indonesia kompetensi dasar menyajikan hasil identifikasi mengenai faktorfaktor penting penyebab penjajahan bangsa Indonesia dan upaya bangsa Indonesia dalam mempertahankan kedaulatannya masih kurang dan pembelajaran kurang efektif sehingga nilai kurang mencapai KKM. Dari 28 siswa yang ada di kelas V, hanya 13 siswa yang nilainya mencapai Kriteria Ketuntasan Minimal (KKM) dengan presentasi siswa mencapai KKM 46,43\% dan presentasi siswa belum mencapai KKM 53,57\% . Dengan kata lain, banyak siswa yang nilainya masih berada dibawah nilai Kriteria Ketuntasan Minimal ( KKM ) yang ditetapkan sekolah yaitu 72 .

Kendala yang dihadapi adalah minat belajar dan aktivitas siswa dalam pembelajaran IPS masih sangat kurang ditambah lagi karena guru mengajar secara monoton, kurang menarik, siswa saling mengandalkan, kegiatan belajar mengajar hanya menggunakan metode berkelompok, sehingga bakat siswa belajar tidak berkembang dan hasil belajar juga rendah. Oleh karena itu, peneliti mencoba memecahkan masalah dan memperbaiki proses pembelajaran tersebut dengan menggunakan pendekatan pembelajaran saintifik (scientific approach) yang merupakan salah satu pendekatan pembelajaran yang menekankan pentingnya penggunaan proses berfikir ilmiah sesuai dengan tingkat perkembangan anak.

\section{METODE PENELITIAN}

Penelitian ini bertujuan untuk meningkatkan hasil belajar IPS materi faktor munculnya rasa kebangsaan di Indonesia melalui pendekatan saintifik. Lokasi penelitian yang dipilih adalah SDN Rawamangun 01 Pagi, Jakarta Timur lebih tepatnya kelas V tahun ajaran 
2019/2020 dengan waktu pelaksanaan dari bulan Februari sampai September 2020.

Jenis penelitian yang digunakan adalah Penelitian Tindakan kelas (PTK) atau Classroom Action Research (CAR). Langkah-langkah tersebut dapat digambarkan dalam gambar 1.

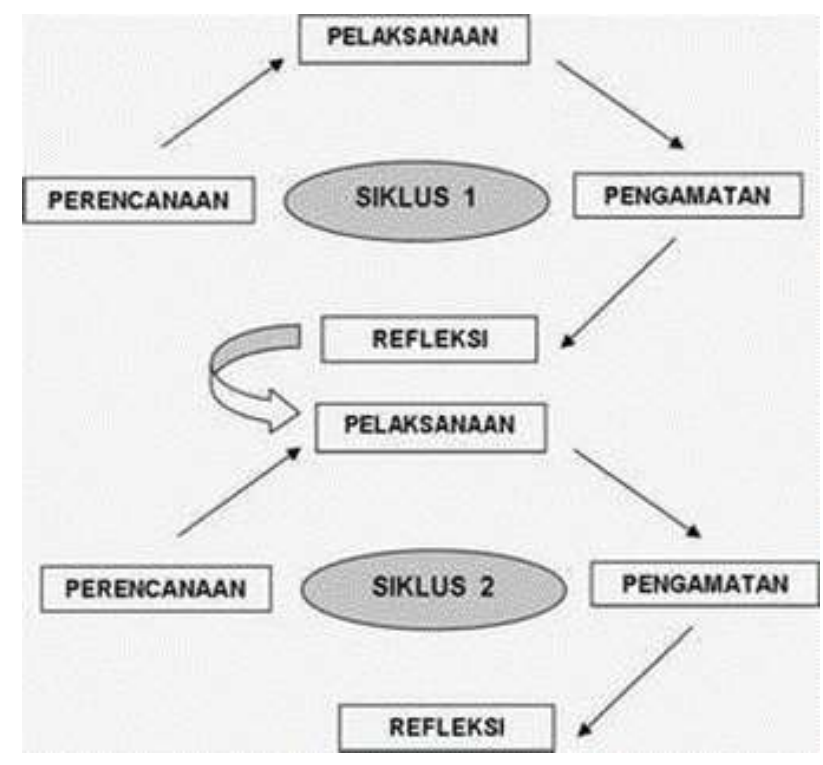

Siklus Pelaksanaan PTK

Gambar 1: Riset Aksi Model John Elliot

Data dalam penelitian ini bersumber dari interaksi guru dengan siswa, serta siswa dengan siswa. Pengumpulan data dalam penelitian ini dilakukan dengan teknik observasi, tes, dokumentasi, wawancara dan catatan lapangan. Teknik analisis data yang digunakan pada penelitian ini adalah :

a. Reduksi Data yakni proses penyederhanaan yang dilakukan melalui seleksi, pemfokusan, dan pengabstraksian data mentah menjadi informasi yang bermakna. Data yang direduksi akan memberikan gambaran yang lebih jelas bagi peneliti untuk pengumpulan data selanjutnya.

b. Deskripsi Data yakni paparan data secara sederhana dalam bentuk naratif dan deskriptif. Penyajian data dimaksudkan untuk mempermudah peneliti untuk melihat gambaran secara keseluruhan atau bagian-bagian tertentu dari peneliti.

c. Verifikasi yakni menguji kebenaran, kekokohan, dan mencocokkan makna-makna yang muncul dari data. Pelaksanaan verifikasi merupakan suatu peninjauan lapangan pada pencatatan lapangan serta tukar pikiran dengan teman sejawat. 
Untuk menganalisis tingkat keberhasilan hasil belajar siswa maka digunakan rumus :

$$
\begin{aligned}
& \text { Keterangan : } \\
& \bar{x} \quad=\text { Nilai rata-rata kelas } \\
& \begin{array}{l}
\sum x=\text { Total nilai yang diperoleh siswa } \\
n \quad=\text { Jumlah siswa }
\end{array}
\end{aligned}
$$$$
\bar{x}=\frac{\sum x}{n}
$$

Selanjutnya, untuk menjamin keabsahan data digunakan teknik kriteria derajat kepercayaan. Derajat kepercayaan yang direncanakan untuk digunakan dalam penelitian ini yaitu ketekunan pengamatan dan triangulasi.

a. Ketekunan Pengamatan yang dilakukan dengan cara peneliti mengadakan pengamatan secara teliti, rinci dan terus menerus selama proses penelitian.

b. Triangulasi Data dengan melihat suatu realitas dari berbagai sudut pandang sehingga lebih akurat. Triangulasi penting dilakukan dalam penelitian tindakan kelas agar kesimpulan penelitiannya sungguh valid, akurat, dan dapat dipercaya.

Penelitian tindakan kelas ini dikatakan berhasil apabila minimal sebagian besar $(80 \%)$ skor hasil belajar siswanya mencapai Kriteria Ketuntasan Minimal (KKM). Adapun Kriteria Ketuntasan Minimal (KKM) yang ditentukan yaitu 71.

\section{TEMUAN DAN PEMBAHASAN}

Penelitian dilakukan pada siswa kelas V SDN Rawamangun 01 Pagi dilakukan dalam 2 siklus. Berdasarkan hasil pada siklus I, II dan III indikator keberhasilan telah dicapai. Indiktor keberhasilan dalam penelitian tersebut adalah apabila siswa yang mendapat $71 \mathrm{di}$ atas $90 \%$. Sebelum diadakan tindakan, terlebih dahulu dilakukan observasi dan wawancara terhadap guru dan siswa.

Berikut ini kondisi awal rentangan prestasi belajar siswa yang didapat dari hasil Belajar sebelum dilakukan tindakan.

Tabel 4.2

Rekapitulasi Ketuntasan Hasil Belajar IPS Pra Siklus

\begin{tabular}{|l|c|c|l|}
\hline Ketuntasan & Jumlah Siswa & Persentase & Ket. \\
\hline Tuntas & 13 & $46,43 \%$ & \\
\hline Belum Tuntas & 15 & $53,57 \%$ & \\
\hline Total & 28 & $100 \%$ & \\
\hline
\end{tabular}


Berdasarkan kenyataan tersebut maka peneliti merasa bahwa perlu adanya tindakan perbaikan dalam proses pembelajaran untuk mengatasi persoalan pembelajaran IPS di kelas sehingga hasil belajar siswa dapat meningkat. Penelitian yang dilakukan oleh peneliti melalui 2 siklus. Siklus I sampai II yang dilakukan peneliti adalah sebagai berikut :

\section{Siklus I}

Pada siklus I dilaksanakan kegiatan-kegiatan sebagai berikut :

\section{Perencanaan}

Peneliti menyusun RPP sesuai dengan kurikulum 2013 yang akan dilaksanakan pada siklus I, menyusun dan mempersiapkan Lembar Kerja Siswa (LKS), menyusun dan mempersiapkan lembar observasi aktivitas guru dan siswa, menyusun lembar wawancara guru dan siswa berisikan daftar pertanyaan, menyusun media pembelajaran berupa power point yang berkaitan dengan materi faktor munculnya rasa kebangsaan di Indonesia.

\section{Tindakan}

Dalam tahap ini, peneliti melakukan langkah-langkah diantaranya peneliti memberikan salam dan mengajak semua siswa berdo'a sesuai dengan agama dan kepercayaannya masingmasing untuk memulai pelajaran. Kemudian guru menginformasikan tema yang akan dibelajarkan dan guru menyampaikan tahapan kegiatan yang meliputi kegiatan mengamati, menanya, mengeksplorasi, mengkomunikasikan dan menyimpulkan. Lalu melakukan tanya jawab ulang tentang materi yang telah diajarkan, guru mengingatkan siswa untuk mempelajari kembali materi yang telah diajarkan, guru menyampaikan materi pembelajaran untuk pertemuan selanjutnya dan yang terakhir mengajak siswa untuk berdo'a sesuai dengan agama dan kepercayaannya masing-masing.

\section{Pengamatan}

Berdasarkan hasil observasi pada siklus I yaitu dengan menggunakan penerapan pendekatan saintifik diperoleh temuan data penelitian sebagai mana berikut, sebanyak $39,29 \%$ siswa masih belum memperhatikan penjelasan guru dengan baik, belum antusias untuk mengikuti proses pembelajaran dan masih sibuk dengan kegiatannya masing-masing. Dan untuk persentasi observasi guru mendapat 53,57\%. Hal ini menyebabkan hasil belajar siswa belum memuaskan.

Adapun rekapitulasi ketuntasan dapat dilihat pada tabel berikut. 
Tabel 4.4

Rekapitulasi Ketuntasan Hasil Belajar IPS Siklus I

\begin{tabular}{|c|c|c|c|}
\hline Ketuntasan & Jumlah Siswa & Persentase & Ket. \\
\hline Tuntas & 17 & $60,71 \%$ & \\
\hline Belum Tuntas & 11 & $39,29 \%$ & \\
\hline Total & 28 & $100 \%$ & \\
\hline
\end{tabular}

Jika dilihat melalui grafik, rekapitulasinya sebagai berikut.

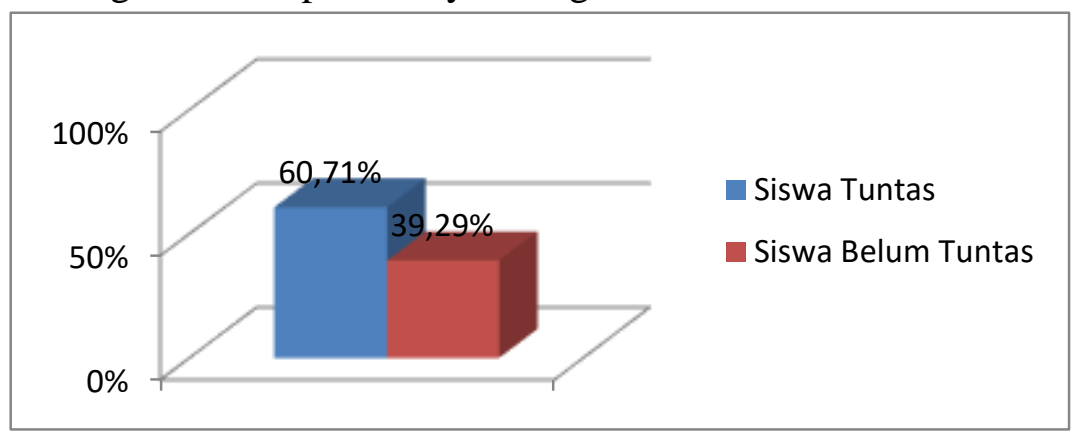

Grafik 4.2

Hasil belajar IPS siklus I

Tes hasil belajar yang telah dilaksanakan pada siklus I mendapat nilai rata-rata kelas 72,00 dengan persentase banyak siswa yang tuntas 60,71\% yakni sebanyak 17 siswa dan persentase siswa belum tuntas sebesar 39,29 \% yakni 11 siswa. Dalam hal ini penerapan pendekatan saintifik yang digunakan dalam proses pembelajaran belum bisa meningkatkan hasil belajar di kelas V SDN Rawamangun 01 Pagi.

\section{Refleksi}

Kekurangan dari siklus I dapat dilihat pada tabel.

\section{Tabel 4.5}

\section{Refleksi Siklus I}

\begin{tabular}{|c|l|l|}
\hline No & \multicolumn{1}{|c|}{ Guru } & \multicolumn{1}{c|}{ Siswa } \\
\hline 1 & $\begin{array}{l}\text { Kurang menarik perhatian siswa } \\
\text { dalam menyampaikan materi }\end{array}$ & $\begin{array}{l}\text { Siswa saling mengandalkan teman } \\
\text { satu kelompoknya }\end{array}$ \\
\hline 2 & $\begin{array}{l}\text { Cara penyampaian materi yang } \\
\text { kurang jelas dan penggunaan } \\
\text { bahasa serta media yang sulit }\end{array}$ & $\begin{array}{l}\text { Kesadaran siswa kurang dan } \\
\text { masih ada siswa yang tidak } \\
\text { memperhatikan saat guru }\end{array}$ \\
\hline
\end{tabular}




\begin{tabular}{|l|l|l|}
\hline & dipahami oleh siswa & menjelaskan \\
\hline \multirow{3}{*}{3} & Kurang memberikan bimbingan & Siswa masih banyak yang enggan \\
& untuk bertanya kepada guru \\
& yang pasif & mengenai materi yang belum \\
& & dipahami \\
\hline
\end{tabular}

Berdasarkan data pada tabel 4.1 menunjukkan bahwa terdapat beberapa permasalahan yang perlu diperhatikan dan diperbaiki untuk direncanakan kembali pada siklus II.

\section{Siklus II}

Peneliti menggambarkan proses pembelajaran IPS materi faktor munculnya rasa kebangsaan di Indonesia sebagai berikut :

\section{Perencanaan}

Peneliti menyusun RPP sesuai dengan kurikulum 2013 yang akan dilaksanakan pada siklus I, menyusun dan mempersiapkan Lembar Kerja Siswa (LKS), menyusun dan mempersiapkan lembar observasi aktivitas guru dan siswa, menyusun lembar wawancara guru dan siswa berisikan daftar pertanyaan, menyusun media pembelajaran berupa power point yang berkaitan dengan materi faktor munculnya rasa kebangsaan di Indonesia.

\section{Tindakan}

Dalam tahap ini, peneliti melakukan langkah-langkah diantaranya peneliti memberikan salam dan mengajak semua siswa berdo'a sesuai dengan agama dan kepercayaannya masingmasing untuk memulai pelajaran. Langkah selanjutnya guru menyampaikan kompetensi yang ingin dicapai dalam materi faktor munculnya rasa kebangsaan di Indonesia, guru menyajikan lirik lagu peninggalan kerajaan islam di Pulau Jawa (Tombo Ati). Setelah itu siswa dengan bantuan guru mencoba untuk memahami makna dari lirik lagu terserbut dan mengaitkannya dengan pemahaman tentang nilai-nilai peninggalaan kerajaan islam. Lalu melakukan tanya jawab ulang tentang materi yang telah diajarkan, guru mengingatkan siswa untuk mempelajari kembali materi yang telah diajarkan, guru menyampaikan materi pembelajaran untuk pertemuan selanjutnya dan yang terakhir mengajak siswa untuk berdo'a sesuai dengan agama dan kepercayaannya masing-masing. 


\section{Pengamatan}

Adapun rekapitulasi ketuntasan dapat dilihat pada tabel berikut.

Tabel 4.8

Rekapitulasi Ketuntasan Hasil Belajar IPS Siklus II

\begin{tabular}{|c|c|c|c|}
\hline Ketuntasan & Jumlah Siswa & Persentase & Ket \\
\hline Tuntas & 23 & $82,14 \%$ & \\
\hline Belum Tuntas & 5 & $37,86 \%$ & \\
\hline Total & 23 & $100 \%$ & \\
\hline
\end{tabular}

Jika dilihat melalui grafik, rekapitulasinya sebagai berikut.

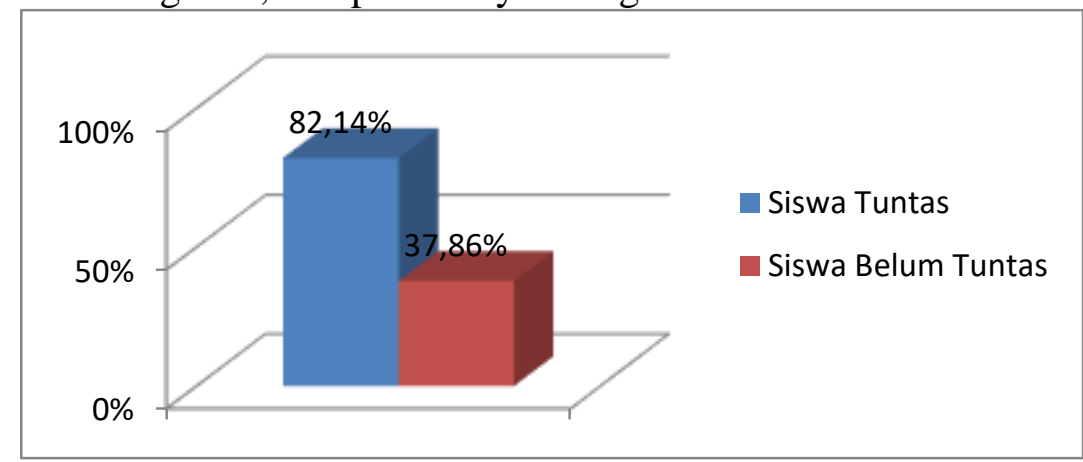

Grafik 4.3

Hasil belajar IPS siklus II

Tes hasil belajar yang telah dilaksanakan pada siklus II mendapat nilai rata-rata kelas81,25 dengan persentase banyak siswa yang tuntas 82,14\% yakni sebanyak 23 siswa dan prosentase siswa yang belum tuntas sebanyak 37,86\% yakni 5 siswa.

Dalam hal ini penerapan pendekatan saintifik yang digunakan dalam proses pembelajaran sudah dapat meningkatkan hasil belajar di kelas V SDN Rawamangun 01 Pagi

\section{Refleksi}

Hasil refleksi siklus II menunjukkan peningkatan terhadap hasil belajar siswa dari siklus ke siklus. Peningkatan pada setiap siklus pada tes hasil belajar meningkat dari ketuntasan $67,36 \%$ pada pra siklus menjadi $69,71 \%$ pada siklus I dan $82,14 \%$ pada siklus II. Dari hasil siklus II menunjukkan hasil yang lebih tinggi dari siklus I dan hasil tersebut sudah memenuhi kriteria keberhasilan penelitian yang diharap oleh peneliti dengan ketuntasan sebesar $90 \%$. Sehingga tidak perlu dilanjutkan pada siklus berikutnya. Berikut tabel rekapitulasi hasil belajar IPS 
Tabel 4.10

Rekapitulasi Pencapaian Hasil Belajar IPS

\begin{tabular}{|l|l|l|l|l|}
\hline Siklus & Tuntas & Belum Tuntas & Total & Ket. \\
\hline \multirow{2}{*}{ Pra Siklus } & 13 Siswa & 15 Siswa & 28 Siswa & \\
\cline { 2 - 5 } & $46,43 \%$ & $53,57 \%$ & $100 \%$ & \\
\hline \multirow{2}{*}{ Siklus I } & 17 Siswa & 11 Siswa & 28 Siswa & \\
\cline { 2 - 5 } & $60,71 \%$ & $39,29 \%$ & $100 \%$ & \\
\hline \multirow{2}{*}{ Siklus II } & 23 Siswa & 5 Siswa & 28 Siswa & \\
\cline { 2 - 5 } & $82,14 \%$ & $17,86 \%$ & $100 \%$ & \\
\hline
\end{tabular}

Sedangkan grafik rekapitulasi hasil belajar dapat dilihat sebagai berikut.

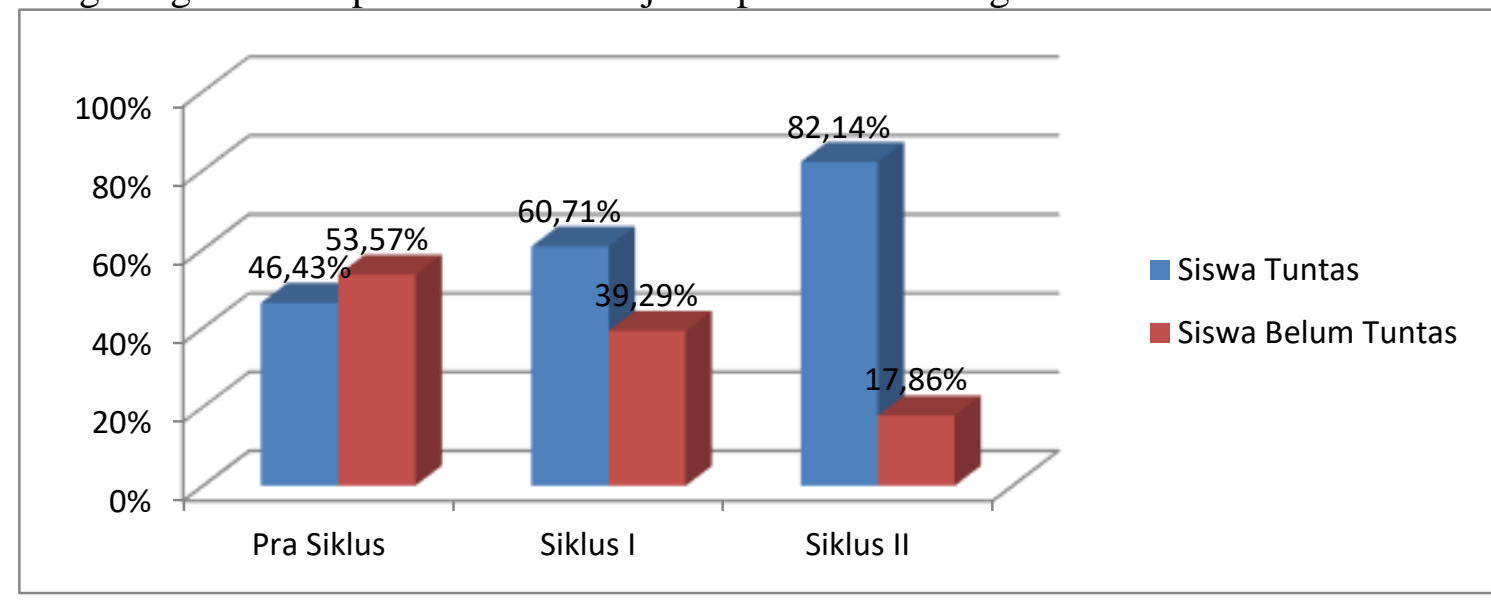

Grafik 4.4

Rekapitulasi Peningkatan Hasil Belajar IPS

Dari tes hasil belajar siswa pada pra siklus diperoleh rerata 67,36 dimana siswa yang sudah memenuhi Kriteria Ketuntasan Minimal (KKM) hanya 13 siswa dengan persentase ketuntasan sebesar 45,43\%. Pada siklus I rerata hasil belajar siswa mengalami peningkatan menjadi 69,71 dengan persentase ketuntasan 60,71\% sebanyak 17 siswa yang nilainya sudah mencapai Kriteria Ketuntasan Minimal (KKM). Persentasi peningkatan dari pra siklus ke siklus I yakni sebesar 2,35\%. Pada siklus II rerata hasil belajar siswa mencapai 81,25 dengan persentase ketuntasan sebesar 86,95\% sebanyak 23 siswa yang berhasil mencapai Kriteria Ketuntasan Minimal. Persentase peningkatan dari siklus I ke siklus II yakni sebesar 26,24\%.Berdasarkan uraian di atas, siswa mengalami peningkatan hasil belajar pada setiap siklusnya. Sehingga dapat dikatakan bahwa penerapan pendekatan saintifik sudah dapat meningkatkan hasil belajar siswa pada mata pelajaran IPS sehingga tidak perlu dilanjutkan pada siklus berikutnya. 


\section{KESIMPULAN}

Berdasarkan hasil penelitian tindakan kelas yang dilakukan dari bulan April sampai dengan Juni 2020, maka diperoleh kesimpulan bahwa Penerapan Pendekatan Saintifik dapat meningkatkan hasil belajar siswa kelas V SDN Rawamangun 01 Pagi pada mata pelajaran IPS materi Faktor Munculnya Rasa Kebangsaan di Indonesia tahun pelajaran 2019/2020, hal ini dapat ditunjukkan berdasarkan tes hasil belajar siswa pada pra siklus diperoleh persentase siswa yang tuntas sebesar 52,17\% dengan rerata kelas 63,48 menjadi 69,57\% dengan rerata kelas 70,22 pada siklus I dan meningkat lagi menjadi $86,95 \%$ dengan rerata kelas 82,83 pada siklus II.

\section{DAFTAR PUSTAKA}

Dimyati dan Mudjiono. Belajar dan Pembelajaran. (Jakarta: Rineka Cipta, 2015.

Dr. Susanto, Ahmad. Teori Belajar dan Pembelajaran di Sekolah Dasar. (Jakarta: Prenadamedia Group, 2019.

Dr. Yani Ahmad, Dr Ruhimat Mamat, Teori dan Implementasi Pembelajaran Saintifik Kurikulum 2013, Bandung: PT Refika Aditama 2019.

Hanifah, Nurdinah. Memahami Penelitian Tindakan Kelas. $\quad$ Bandung: UPIPress, 2014.

Hidayat, Syarif dan Asep. Penelitian Tindakan Kelas. Tangerang: PustakaMandiri, 2015.

Nana, Sudjana. Penillaian Hasil Proses Belajar Mengajar. Bandung : PT. Remaja Rosdakarya, 2017.

Sudjana, Nana. Penilaian Hasil Proses Belajar Mengajar. Bandung: PT Remaja Rosdakarya, 2017.

Sumantri, Mohamad Syarif. Strategi Pembelajaran. Depok: PT Raja Grafindo Persada, 2015.

Wisudawati, Asih Widi. Metodologi Pembelajaran IPS. Jakarta: Bumi Aksara, 2013.

Yudha, B. C. (2019). Penerapan Project Based Learning dalam Mata Kuliah Penelitian Tindakan Kelas. Dwija Cendekia Jurnal Riset Pedagogik. 30-4 